\title{
PANELIST'S LEVEL OF FAVOR FOR NATURAL NON-MSG FLAVOR FROM DIFFERENT FISH MEAT
}

\author{
Teni Novianti \\ Fakultas Teknologi Kelautan dan Perikanan, Universitas Nahdlatul Ulama Cirebon \\ Jalan Sisingamangaraja No. 33 Cirebon 45112, Jawa Barat, Indonesia \\ teninovianti.83@gmail.com
}

Doi: $10.31943 /$ mangiferaedu.v6i1.116

Received: December 29, 2020 Accepted: May 17, $2021 \quad$ Published: July 31, 2021 Citation: Novianti, T., (2021). Panelist's Level Of Favor For Natural Non-Msg Flavor From Different Fish Meat. Jurnal Mangifera Edu, 6(1), 56-67.

\section{ABSTRACT}

The purpose of this study was to determine the level of preference for the panelists to natural non-MSG flavorings made from different fish meat. The procedure in this study is the manufacture of natural flavorings from long jawed mackerel and fish float, calculation of fish yield and analysis of the level of preference of the panelists to natural non-MSG flavorings from different fish meat. Based on the results of the study, the processing stages of non-MSG natural flavoring made from fish include the process of selecting raw materials, washing I, filling, washing II, refining I, weighing I, drying, refining II, sifting, weighing II and packaging. The amount of fish yield that can be used as the main raw material for making natural non-MSG flavorings is 50-53\%. The analysis test of the level of preference for the panelists to the natural non-MSG flavorings of different fish meat showed that the level of preference for the taste and aroma of the fish float flavor was preferred compared to the taste and aroma of the long jawed mackerel flavor. This is because the taste and aroma produced from glutamic acid in the flavor of the fish float is stronger. The level of liking for the flavoring textures of long jawed mackerel and fish float were 6.6 and 6.2 respectively (rather like). Meanwhile, the level of preference for the flavoring of long jawed mackerel fish is more preferred than the fish float with the value of the level of preference for the flavor of long jawed mackerel is 7.4 (likes).

Keywords: Favorite level, Natural flavoring, Long jawed mackerel, Fish float

\section{ABSTRAK}

Tujuan dari penelitian ini adalah untuk mengetahui tingkat kesukaan panelis terhadap perisa alami non MSG berbahan dasar daging ikan yang berbeda. Prosedur dalam penelitian ini adalah pembuatan perisa alami dari ikan kembung rahang panjang dan pelampung, perhitungan hasil ikan dan analisis tingkat kesukaan panelis terhadap perasa alami non MSG dari daging ikan yang berbeda. Berdasarkan hasil penelitian, tahapan pengolahan penyedap rasa alami non MSG berbahan dasar ikan meliputi proses pemilihan bahan baku, pencucian I, pengisian, pencucian II, pemurnian I, penimbangan I, pengeringan, pemurnian II, pengayakan, penimbangan II dan kemasan. Jumlah rendemen ikan yang dapat digunakan sebagai bahan baku utama pembuatan penyedap rasa alaminon MSG adalah 50-53\%. Hasil uji analisis tingkat kesukaan panelis terhadap perisa alami non MSG daging ikan yang berbeda menunjukkan bahwa tingkat kesukaan terhadap rasa dan aroma ikan lele lebih disukai dibandingkan dengan rasa dan aroma ikan berahang panjang. rasa makarel. Hal ini dikarenakan rasa dan aroma yang dihasilkan dari asam glutamat pada 
rasa ikan terapung lebih kuat. Tingkat kesukaan terhadap tekstur penyedap rasa ikan tenggiri rahang panjang dan ikan pelampung masing-masing sebesar 6,6 dan 6,2 (agak suka). Sedangkan tingkat kesukaan terhadap rasa ikan tenggiri rahang panjang lebih disukai daripada ikan tenggiri dengan nilai tingkat kesukaan terhadap rasa ikan tenggiri rahang panjang sebesar 7,4 (suka).

Kata Kunci: Tingkat kesukaan, Penyedap rasa alami, Ikan tenggiri rahang panjang, Ikan terapung

\section{PENDAHULUAN}

Sektor perikanan memegang peranan penting dalam perekonomian nasional terutama dalam penyediaan lapangan kerja, sumber pendapatan bagi nelayan, sumber protein hewani dan sumber devisa bagi negara. Isu dan tantangan dalam permasalahan kelautan dan perikanan di Indonesia tentang kebijakan Pembangunan Kelautan dan Perikanan adalah rendahnya nilai tambah produk, dan salah satu tantangannya adalah produk kelautan dan perikanan masih dipasarkan dalam bentuk primer belum diolah dan memiliki nilai tambah kecil (Botutihe \& Rasyid, 2018). Produk hasil perikanan yang berpotensi untuk dikembangkan salah satunya adalah ikan yang tergolong dalam kelompok pelagis kecil seperti ikan kembung (Rastrelliger sp) dan Ikan Layang (Decapterus sp) yang tersebar di daerah pesisir pantai utara jawa terutama di perairan Cirebon dan Indramayu. Jenis ikan tersebut belum dimanfaatkan secara optimal, pada umumnya masyarakat daerah setempat mengolah ikan kembung dengan cara di goreng dan di bumbu kuning atau balado serta mengolah ikan layang sebagai bahan baku ikan pindang.

Ikan kembung dan ikan layang selain mudah ditemukan dipasaran dengan harga yang relatif lebih murah dibandingkan dengan daging sapi atau ayam, akan tetapi juga memiliki kandungan gizi yang cukup tinggi dengan kandungan protein sebesar 17-23\% (Damayati et al., 2017); Fauziah (2017). Selain itu mengandung omega 3 dan omega 6 yang baik bagi pencegahan penyakit, mampu memperbaiki kadar lemak dalam tubuh serta memberikan nutrisi pada otak (Nalendrya et al., 2016). Oleh karena itu ikan kembung dan ikan layang merupakan salah satu bahan pangan yang memiliki kandungan gizi yang baik untuk memenuhi sejumlah besar unsur kesehatan dan memiliki cita rasa yang kuat sehingga menyebabkan rasa umami atau gurih pada produk olahan pangan. Saat ini sebagian besar produk makanan yang beredar di masyarakat diolah menggunakan bahan tambahan pangan baik alami maupun sintetis. Penyedap rasa merupakan suatu bahan tambahan pangan yang sering digunakan dalam makanan yang bertujuan untuk menambah cita rasa ataupun hanya memperkuat flavour dan cita rasa pada makanan tersebut (Azis \& Akolo, 2019). 
Penyedap rasa yang dimiliki oleh makanan umumnya dihasilkan oleh senyawa alami dan senyawa sintetik. Senyawa alami, yaitu bahan pangan yang berasal dari bahan penyedap alami yang sering digunakan biasanya seperti bumbu atau rempah, minyak essensial turunannya dan ekstrak tanaman atau ekstrak senyawa dari hewan. Senyawa sintetis berasal dari komponen atau senyawa kimia yang diproduksi menyerupai penyedap alami (Rahmi et al., 2018). Monosodium Glutamat (MSG) merupakan salah satu penyedap rasa sintetik yang sering digunakan oleh masyarakat untuk bumbu masakan yang menciptakan rasa gurih dan asin (Rangkuti et al., 2012). Menurut Azis \& Akolo (2019), Penggunaan MSG telah diatur oleh BPOM dalam peraturan Nomor 23 Tahun 2013 tentang batas maksimum penggunaan bahan tambahan pangan penguat rasa. Bahan tambahan tersebut aman digunakan asalkan masih memenuhi standar yang ditetapkan oleh pemerintah. Namun, penggunaan bahan tambahan sintesis yang berlebihan dan dalam jangka waktu yang panjang dan intensitas waktu yang sering dapat mengakibatkan kerugian terhadap kesehatan di masa mendatang.

Oleh karena itu, perlu alternatif lain pengganti penyedap rasa sintesis yang dapat dikembangkan dari penyedap rasa alami dengan memanfaatkan hasil perikanan yang memiliki cita rasa dan aroma yang baik untuk dikembangkan menjadi olahan bumbu penyedap rasa pada masakan. Berdasarkan masalah tersebut penelitian ini bertujuan untuk mengetahui tingkat kesukaan panelis terhadap penyedap rasa alami non MSG yang dibuat dari daging ikan yang berbeda. Menurut Azis \& Akolo (2019), penyedap rasa alami yang dibuat harus dilakukan pengujian organoleptik hedonik (tingkat kesukaan) yang menyatakan bahwa beberapa panelis menyukai atau tidak menyukai penyedap rasa tersebut yang dilihat melalui rasa, aroma, warna dan tekstur.

\section{METODOLOGI PENELITIAN}

\section{Bahan dan Alat}

Proses pengolahan dan pengujian untuk penyedap rasa alami membutuhkan bahan dan alat yaitu sebagai berikut : Bahan baku utama yaitu ikan kembung (Rastrelliger spp) dan ikan layang (Decapterus sp) masing-masing $2 \mathrm{~kg}$ (volume formulasi $84 \%$ ). Sedangkan bahan bumbu penyedap rasa (volume formulasi $16 \%$ ) dengan komposisi bahan sebagai berikut : 1). Garam 2,11\%; Gula 1,3\%; 2). Bawang Merah 4,59 \%; 3). Bawang Putih $6 \%$; 4). Kunyit $1 \%$ dan 5\%. Lada $1 \%$. Bahan untuk analisa organoleptik: Mie cup yang akan dicampurkan dengan penyedap rasa alami, air penetral.

Alat pembuatan penyedap rasa alami: alat yang digunakan untuk membuat peyedap rasa adalah pisau, talenan, baskom, oven, blender, timbangan, ayakan (saringan), loyang dan 
sendok. alat untuk pengajuan organoleptik : sendok, wadah sampel, bilik pencicipan dan formulir penilaian.

\section{Metode}

Penelitian ini meliputi pembuatan penyedap rasa alami non msg dari bahan baku daging ikan yang berbeda yaitu ikan kembung dan ikan layang dengan formulasi rempah-rempah dan proses pengolahan yang digunakan dalam penelitian ini mengacu pada penelitian Fauziah (2017); Azis \& Akolo (2019). Masing-masing ikan yang digunakan sebagai bahan baku pembuatan penyedap rasa dilakukan perhitungan rendemen ikan untuk memperkirakan banyaknya presentase bagian tubuh ikan yang dapat digunakan sebagai bahan penyedap rasa alami non msg. kemudian penyedap rasa yang dihasilkan dilakukan analisa organoleptik kesukaan (uji hedonik) mengacu pada Setyaningsih et al., 2010.

\section{Persiapan Sampel}

Pembuatan bumbu penyedap rasa alami non MSG berbahan dasar ikan dilakukan dengan beberapa tahapan yaitu meliputi proses pemilihan bahan baku, pencucian i, pemfilletan, pencucian ii, penghalusan i, penimbangan i, pengeringan, penghalusan ii, pengayakan, penimbangan ii dan pengemasan (Fauziah, 2017; Azis dan Akolo, 2019). adapun formulasi bahan yang digunakan dalam penelitian ini yaitu ikan kembung $84 \%$ dan sisanya $16 \%$ adalah campuran penambahan bumbu dan rempah-rempah seperti gula, garam, bawang merah, bawang putih, kunyit dan merica. kemudian semua bahan dicampur sampai homogen. bahan yang telah tercampur dihaluskan menggunakan blender dan diayak menggunakan ayakan 60 mesh. adapun diagram alir pembuatan penyedap rasa alami non msg berbahan baku ikan kembung dan ikan layang dapat dilihat pada Gambar 1. 


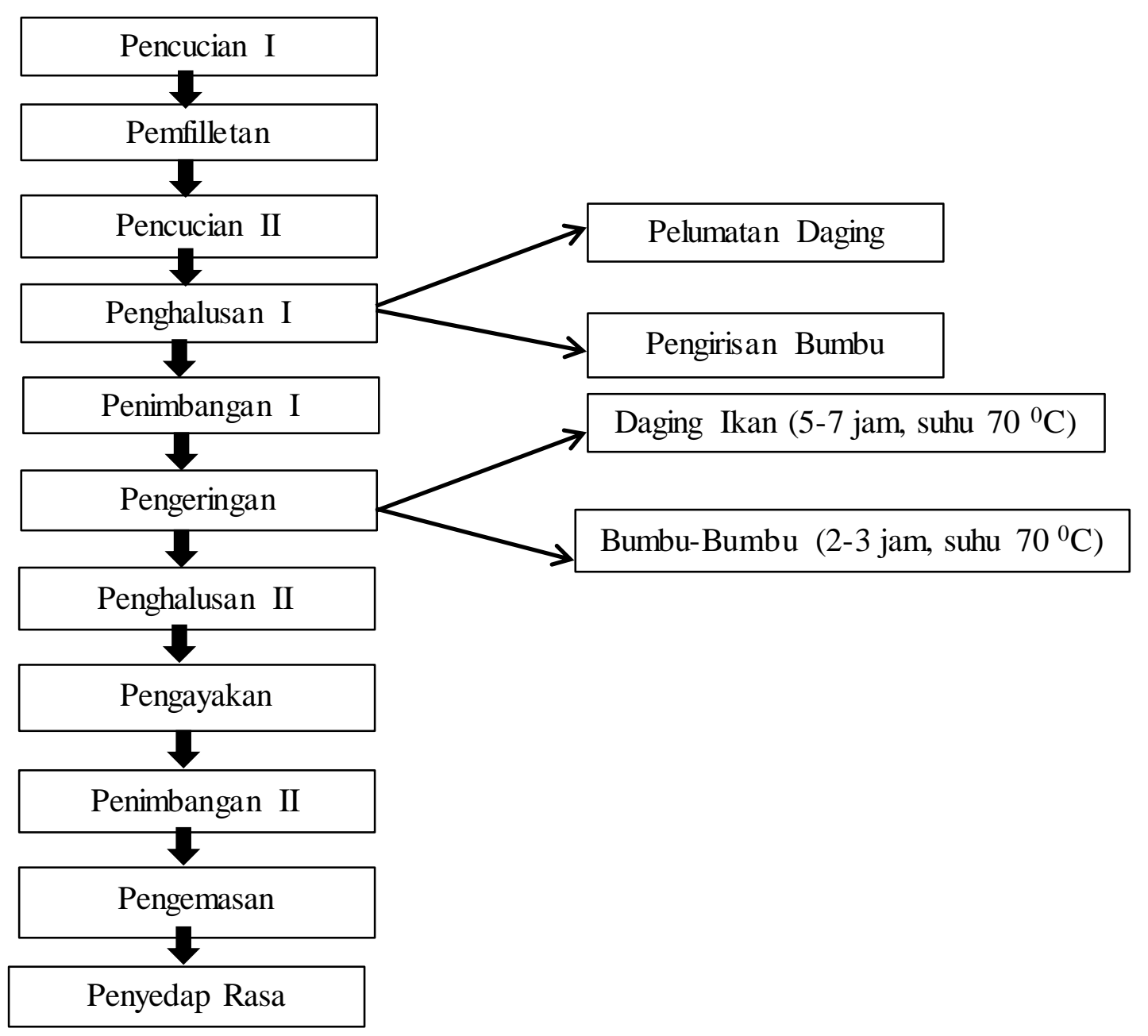

Gambar 1. Diagram alir pembuatan penyedap rasa alami non MSG berbahan baku ikan kembung dan ikan layang

Uji kesukaan juga disebut uji hedonik dilakukan dari hasil optimasi yang terbaik dengan empat kriteria mutu yaitu rasa, warna, aroma dan tekstur. Panelis yang digunakan adalah panelis tidak terlatih dengan jumlah 30 orang. Panelis dimintakan tanggapan pribadinya tentang kesukaan atau sebaliknya (ketidaksukaan). Disamping panelis mengemukakan tanggapan senang, suka atau kebalikannya, mereka juga mengemukakan tingkat kesukaannya. Tingkat-tingkat kesukaan ini disebut skala hedonik. Pada penelitian ini digunakan 9 skala hedonik dengan urutan skala 1 menyatakan amat sangat tidak suka, skala 2 menyatakan sangat tidak suka, skala 3 menyatakan tidak suka, skala 4 menyatakan agak tidak suka, skala 5 menyatakan netral, skala 6 menyatakan agak suka, skala 7 menyatakan suka, skala 8 menyatakan sangat suka dan skala 9 menyatakan amat sangat suka. 


\section{HASIL DAN PEMBAHASAN}

\section{Karakteristik Organoleptik Bahan Baku Ikan untuk Penyedap Rasa}

Proses pengolahan penyedap rasa dari daging ikan perlu adanya pemilihan bahan baku sebagai langkah awal pengolahan penyedap rasa alami non MSG. Langkah awal ini dilakukan dengan memastikan kualitas bahan baku yang digunakan segar agar produk yang dihasilkan bermutu baik dan aman sehingga menghasilan produk yang bermutu baik pula. Berdasarkan hasil penelitian karakteristik organoleptik ikan yang digunakan sebagai bahan baku pembuatan penyedap rasa disajikan pada Tabel 1 .

Tabel 1. Karakteristik organoleptik ikan kembung dan ikan layang

\begin{tabular}{ll}
\hline \multicolumn{1}{c}{ Karakteris tik Organole ptik } & Deskripsi Organoleptik Ikan Kembung \\
\hline Kenampakan & Cermerlang dan mengkilap \\
Mata & Cerah, bening, dan menonjol \\
Insang & Berwarna merah segar \\
Bau & Bau khas ikan laut segar \\
Tekstur & Elastis dan padat \\
\hline
\end{tabular}

Menurut Indriati et al. (2006); Fauziah (2017), jenis ikan pelagis kecil seperti ikan kembung dan ikan layang memiliki kandungan daging merah yang biasanya mengandung senyawa histamin didalamnya. Akan tetapi histamin tidak terbentuk bila ikan disimpan dalam es, diduga hal ini berkaitan dengan efek pencucian (leaching) oleh es yang meleleh terhadap bakteri pembentuk histamin atau histamin yang terbentuk. Selain itu pembentukan histamin pada suhu $0-5^{0} \mathrm{C}$ dapat diabaikan meskipun sebelumnya ikan telah disimpan pada suhu yang lebih tinggi.

Berdasarkan hasil penelitian Naimah \& Ningsih (2014), Bahan baku ikan yang diterima dalam proses pengolahan harus dalam kondisi bebas dari bahaya fisik, biological dan kimiawi. Bahaya fisik meliputi kayu, jaring atau metal fragment yang mungkin terbawa dari supplier. Sedangkan bahaya biological disebabkan oleh pertumbuhan bakteri yang bisa menyebabkan pembusukan pada ikan seperti TPC, E-coli, coliform dan salmonella yang mungkin terbawa dari supplier atau terkontaminasi dari lingkungan sekitar. Dan yang terakhir bahaya kimia seperti $\mathrm{Pb}, \mathrm{Cd}$ dan $\mathrm{Hg}$ yang kemungkinan terjadi atau terkontaminasi dari makanan ikan itu ataupun pada saat proses pemancingan itu sendiri Critical limit untuk $\mathrm{Pb} 0.3 \mathrm{mg} / \mathrm{kg}$ untuk $\mathrm{Cd} 0.05 \mathrm{mg} / \mathrm{kg}$ dan untuk $\mathrm{Hg} 0.5 \mathrm{mg} / \mathrm{kg}$. Setelah ikan dicuci bersih maka dilakukan pemfilletan untuk memisahkan bagian daging, kulit, dan tulangnya. Dalam pembuatan penyedap bubuk dari ikan ini hanya menggunakan bagian daging ikan saja. Dalam proses pemfilletan harus dilakukan secara hati-hati agar tidak mengurangi rendemen daging ikan tersebut (Fauziah, 2017). 
Rendemen merupakan rasio berat antara daging dengan berat ikan utuh. Perhitungan rendemen ikan digunakan untuk memperkirakan banyaknya bagian tubuh ikan yang dapat digunakan sebagai bahan baku penyedap rasa alami non MSG dengan daging ikan pilihan. Berdasarkan hasil penelitian terhadap jumlah rendemen ikan yang digunakan sebagai bahan baku penyedap rasa yaitu berkisar antara 50-53 \%. Hasil tersebut sesuai dengan hasil penelitian Hafiludin (2011), Secara umum bagian ikan yang dapat dimakan (edible portion) berkisar antara 45-50\% dari tubuh ikan. Jumlah rendemen untuk ikan tongkol (Euthynnus affinis) berkisar antara $50 \%$ dengan komposisi daging puth lebih banyak dari pada daging merah yaitu 37,18 \% daging putih dan sisanya 12,82\% daging merah. Sedangkan jumlah rendemen ikan tuna sebesar 56,4 \% dengan komposisi daging putih sebesar 36,4\% dan daging merah sebesar 20\%. Diperkuat dengan hasil penelitian Herminiati dan Rahman (2008), rendemen fillet ikan berbeda-beda tergantung jenis ikannya yang berkisar antara 29,27 - 45,97 \%. Rendemen fillet ikan yang terkecil diperoleh pada ikan mata besar dengan jumlah presentase rendemen sebesar 29,27\% dan rendemen terbesar diperoleh pada ikan kembung. Secara umum dapat dikatakan bahwa ikan yang berdaging tebal memiliki rendemen fillet yang lebih besar dibandingkan dengan ikan yang berdaging tipis.

\section{Analisa Tingkat Kesukaan Panelis (Uji Hedonik)}

Analisa tingkat kesukaan (uji hedonik) merupakan suatu cara penilaian menggunakan indera manusia yang paling banyak dilakukan dalam menentukan tingkat kesukaan panelis dari suatu produk olahan pangan (Bawinto, 2015). Pengujian hedonik pada penyedap rasa alami dari daging ikan yang berbeda bertujuan untuk mendapatkan gambaran tingkat kesukaan panelis terhadap warna, rasa, aroma dan tekstur yang dihasilkan. Adapun hasil yang diperoleh terhadap analisa tingkat kesukaan panelis dapat dilihat pada Gambar 2 . 


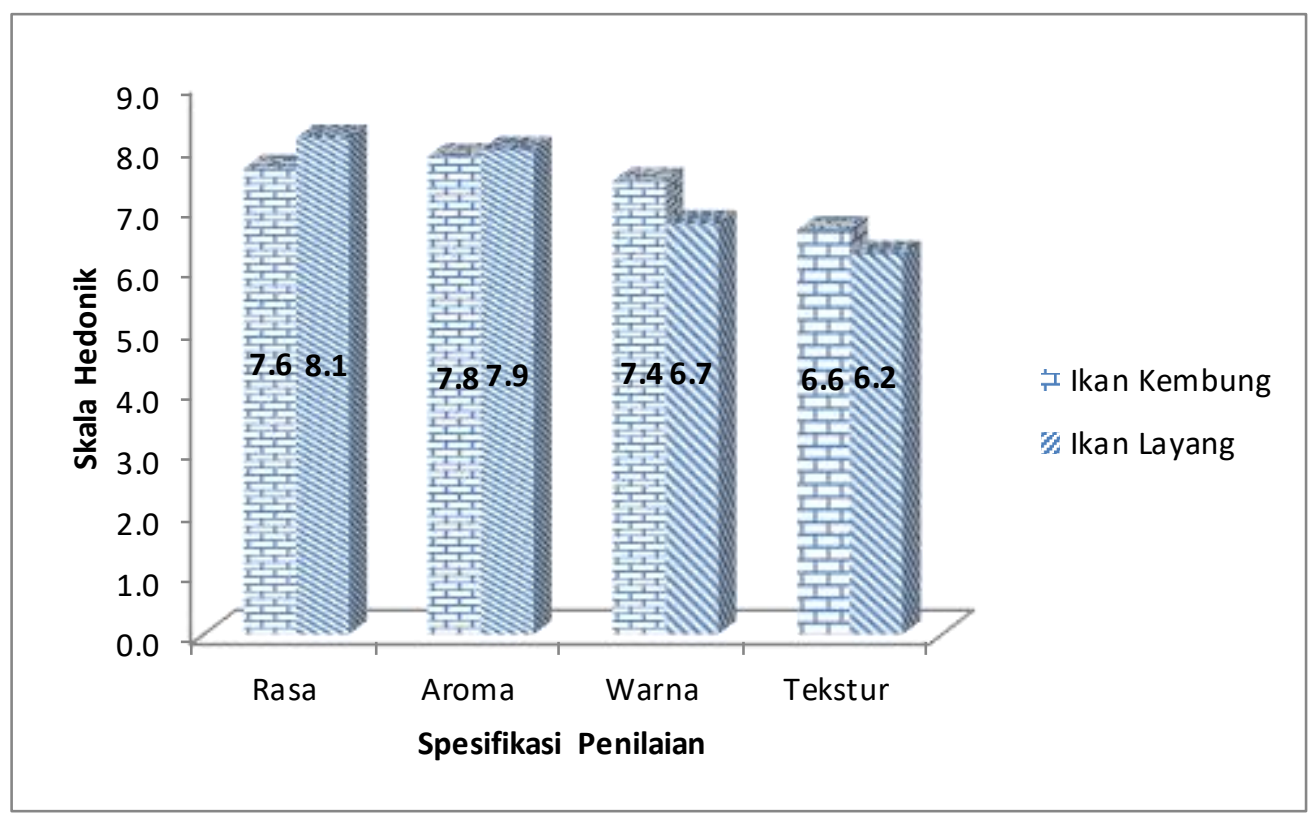

Gambar 2. Analisa tingkat kesukaan panelis pada penye dap rasa daging ikan

\section{Warna}

Warna produk pangan merupakan kesan pertama yang ditangkap oleh panelis sebelum mengenali rangsangan-rangsangan yang lain. Warna merupakan komponen yang sangat penting untuk menentukan kualitas atau derajat penerimaan suatu bahan pangan atau produk pangan. Selain itu, warna dapat digunakan sebagai petunjuk mengenai perubahan kimia pada bahan pangan seperti reaksi pencoklatan dana karamelisasi (Tahir et al., 2014). Berdasarkan hasil penelitian, diperoleh data uji hedonik terhadap warna penyedap rasa alami dari daging ikan yang berbeda yaitu didapatkan nilai rata-rata sebesar 7,4 yang berarti panelis suka terhadap warna penyedap rasa ikan kembung. Sedangkan pada warna penyedap rasa ikan layang diperoleh tingkat kesukaan yang berbeda dengan nilai rata-rata sebesar 6,7 yang berarti panelis agak suka terhadap warna penyedap rasa ikan layang. Warna yang dihasilkan ikan kembung lebih disukai karena berwarna cokelat terang, sedangkan warna pada penyedap rasa ikan layang lebih gelap. Menurut Botutihe dan Rasyid (2018), tingkat kesukaan warna pada bumbu bubuk berbahan dasar ikan dipengaruhi oleh adanya senyawa karbonil dan fenol yang terdapat pada daging ikan dan berkontribusi pada proses pemanasan atau pengeringan sehingga dapat menghasilkan warna cokelat-kuning keemasan.

\section{Rasa}

Rasa merupakan faktor yang cukup penting dari suatu produk olahan pangan. Pada umumnya bahan pangan tidak hanya terdiri dari salah satu rasa, tetapi merupakan gabungan berbagai macam rasa secara terpadu sehingga menimbulkan cita rasa yang utuh. Menurut 
Pratama et al., (2012), Rasa makanan merupakan parameter yang sangat penting dalam menentukan tingkat penerimaan konsumen terhadap suatu produk makananan. Senyawa aktif pembentuk rasa (taste-active-components) pada umumnya ialah senyawa nonvolatil, seperti asam amino bebas, nukleotida, gula, garam-garam mineral, basa organik, asam organik, dan senyawa inorganik. Berdasarkan data uji hedonik terhadap penyedap rasa alami yang telah diuji dengan menggunakan mie cup yaitu didapatkan hasil respon dari 30 panelis terhadap rasa dengan nilai rata-rata yaitu 7,6 yang berarti panelis suka terhadap penyedap rasa ikan kembung. Sedangkan tingkat kesukaan rasa pada penyedap rasa ikan layang didapatkan hasil lebih baik yaitu dengan nilai rata-rata 8,1 yang berarti panelis sangat suka terhadap penyedap rasa dari daging ikan layang. Oleh karena itu, rasa yang paling disukai oleh panelis dari penyedap rasa alami non MSG berdasarkan daging ikan yang berbeda yaitu ikan layang karena cita rasanya lebih kuat dibandingkan dengan ikan kembung sehingga dapat disimpulkan bahwa penyedap rasa ikan layang sangat disukai seperti yang diharapkan dari suatu penyedap rasa yang dapat memberikan rasa gurih dan menambah suatu cita rasa yang enak pada suatu makanan, sama hal nya dengan penyedap rasa sintetik yang selama ini beredar di masyarakat. Selain itu penyedap rasa alami lebih menguntungkan untuk dikonsumsi karena memberikan tambahan nutrisi dan tidak memberikan dampak buruk bagi kesehatan (Azis dan Akolo, 2019).

\section{Aroma}

Aroma dari suatu bahan pangan sangat menentukan kelezatan makanan tersebut. Industri makanan menganggap sangat penting melakukan uji aroma karena dengan cepat dapat memberikan hasil penilaian produksinya disukai atau tidak disukai (Tahir et al., 2014). Berdasarkan data hasil uji hedonik terhadap aroma penyedap rasa alami non MSG diperoleh tingkat kesukaan yang sama dari 30 panelis terhadap aroma penyedap rasa ikan yang berbeda. Masing-masing dengan nilai rata-rata yaitu 7,8 (penyedap rasa ikan kembung) dan 7,9 (penyedap rasa ikan layang) yang berarti panelis suka terhadap penyedap rasa alami dari ikan tersebut. Pengaruh kesukaan panelis pada aroma kemungkinan dipengaruhi oleh senyawa yang terdapat pada ikan kembung dan ikan layang. Berdasarkan penelitian Djohar et al., 2018, diperoleh hasil bahwa ikan mengandung asam glutamat yang akan berpengaruh terhadap aroma yang dihasilkan dari penyedap rasa alami. Selain itu, aroma pada bumbu juga dipengaruhi oleh rempah-rempah yang ditambahkan. Menurut Botutihe dan Rasyid (2018), bahwa kandungan pada rempah-rempah mempunyai aroma dan rasa (flavor) kuat sehingga penggunaan dalam jumlah sedikit dapat memberikan efek rasa pada makanan. 


\section{Tekstur}

Tekstur merupakan faktor yang turut mempengaruhi analisis sensori produk pada penyedap rasa alami dari daging ikan. Berdasarkan data hasil uji hedonik terhadap tekstur penyedap rasa alami non MSG dari daging ikan yang berbeda diperoleh tingkat kesukaan yang menunjukan perbedaan tekstur yang tidak begitu besar. Hasil penelian terhadap penyedap rasa alami yang telah diuji dengan menggunakan mie cup yaitu didapatkan hasil respon dari 30 panelis terhadap tekstur penyedap rasa ikan kembung dengan nilai rata-rata yaitu 6,6 dan tekstur penyedap rasa ikan layang dengan nilai rata-rata 6,2 yang berarti panelis agak suka terhadap tekstur penyedap rasa yang dihasilkan dari masing-masing daging ikan yang berbeda. Hal ini dikarenakan tekstur penyedap rasa ikan layang dan ikan kembung memiliki tekstur yang kurang halus dan dapat cepat larut dalam suhu yang panas. Menurut hasil penelitian yang diperoleh Azis dan Akolo (2019), bahwa tekstur yang dihasilkan pada penyedap rasa instan dari ikan teri dan ikan nike dipengaruhi oleh perbedaan suhu pengeringan dan lamanya waktu pengeringan di oven, sehingga tingkat kekeringan dapat berpengaruh terhadap tekstur. Tekstur dengan tingkat kesukaan panelis yang terbaik diperoleh pada sampel berbahan dasar ikan nike dengan waktu pengeringan 10 jam dan suhu pengeringan $80{ }^{\circ} \mathrm{C}$.

\section{SIMPULAN}

Dari hasil yang diperoleh dan dibahas maka dapat ditarik kesimpulan yaitu analisis tingkat kesukaan panelis dari penyedap rasa alami non MSG dari daging ikan yang berbeda dengan menggunakan metode uji hedonik adalah rasa dan aroma penyedap rasa ikan layang lebih disukai di bandingkan dengan penyedap rasa ikan kembung. Adapun tingkat kesukaan terhadap tekstur diperoleh hasil dengan menunjukan perbedaan tekstur yang tidak begitu besar antara penyedap rasa daging ikan kembung dan ikan layang. Sedangkan tingkat kesukaan terhadap warna penyedap rasa ikan kembung lebih disukai dari pada ikan layang. 


\section{DAFTAR PUSTAKA}

Azis, R dan I. R. Akolo. 2019. The Characteristic of Moisture Content Quality, Ash Content and Organoleptic on the Instant Flavors. Journal of Agritech Science, 3(2), 60-77.

Bawinto, A.S., E. Mongi dan B.E. Kaseger. 2015. Analisa Kadar Air, pH, Organoleptik dan Kapang pada Produk Ikan Tuna (Thunnus sp) Asap, di Kelurahan Girian Bawah Kota Bitung, Sulawesi Utara. Jurnal Media Teknologi Hasil Perikanan, 3(2),55-65.

Botutihe, F dan N.P. Rasyid. 2018. Mutu Kimia, Organoleptik dan Mikrobiologi Bumbu Bubuk Penyedap Berbahan Dasar Ikan Roa Asap (Hermihampus Far). Jurnal Perbal. 6(3), 16-30.

Damayati, D.S., M.S. Jastam dan N.A. Faried. 2017. Analisis Kandungan Otak-Otak Ikan Kembung (Rastrelliger brachyoma) Subtitusi Buah Lamun (Enhalus acoroides) Sebagai Alternatif Perbaikan Gizi di Masyarakat. Journal Al-Sihah: Public Health Science Journal, 9(1), 19-30.

Djohar, M.A., S.M. Timbowo dan F. Mentang. 2018. Tingkat Kesukaan Panelis Terhadap Penyedap Rasa Alami Hasil Samping Perikanan dengan Edible Coating dari Karagenen. Jurnal Media Teknologi Hasil Perikanan, 6(2), 37-41.

Fauziah, M.F. 2017. Analisis Usaha Pengolahan Ikan Layang (Decapterus sp) Sebagai Penyedap Rasa. Teknologi Pengolahan Hasil Perikanan. Universitas Jenderal Soedirman: Purwokerto

Hafiludin. 2011. Karakteristis Proksimat dan Kandungan Senyawa Kimia Daging Putih dan Daging Merah Ikan Tongkol (Euthynnus affinis). Jurnal Kelautan, 4(1), 1-10.

Herminiati, A dan T. Rahman. 2008. Potensi Fillet Ikan dari Blanakan Perairan Pantura Untuk Bahan Baku Sosis Ikan. Prosiding Seminar Nasional Teknik Kimia: Teknologi Tepat Guna Ramah Lingkungan. B.10-1 - B.10-8. ISBN 978-979-98645-4-9.

Indriati, N., Rispayeni dan E.S. Heruwati. 2006. Studi Bakteri Pembentuk Histamin Pada Ikan Kembung Selama Proses Pengolahan. Jurnal Pascapanen dan Bioteknologi Kelautan dan Perikanan, 1(2), 117-123.

Naimah, H dan I. J. Ningsih. 2014. Process of Freezing Fish Katamba (Lethrinus lentjan) Product WGGS (Whole Gilled Gutted Scaled). Samakia: Jurnal Ilmu Perikanan, 5(2), 80-93.

Nalendrya, I., I.M.B. Ilmi dan F. A. Arini. 2016. Long Jawed Mackerel Fish Sausages (Rastelliger kanugarta L) As Food Sources of Omega 3. Jurnal Aplikasi Teknologi Pangan, 5(3), 71-75.

Pratama, R.I., H. Sumaryanto., J. Santoso dan W. Zahirudin. 2012. Karakteristik Sensori Beberapa Produk Ikan Asap Khas Daerah di Indonesia dengan Menggunakan Metode Quantitative Descriptive Analysis. Jurnal Pascapanen dan Bioteknologi Kelautan dan Perikanan, 7(2). 117-130. 
Rahmi, A.D., H. A. Dien dan J.T. Kaparang. 2018. Mutu Mikrobiologi dan Kimia dari Produk Pasta (Intermediet Product) Penyedap Rasa Alami Yang Disimpan Pada Suhu Ruang dan Suhu Dingin. Jurnal Media Teknologi Hasil Perikanan, 6(2), 42-47.

Rangkuti, R.H., E. Suwarso dan P. Anjelisa. 2012. Pengaruh Pemberian Monosodium Glutamate (MSG) Pada Pembentukan Mikronukleus Sel Darah Merah Mencit. Journal of Pharmaceutics and Pharmalogy, 1(1), 29-36.

Setyaningsih, D., A. Apriyantono dan M.P. Sari. 2010. Analisis Sensori Untuk Industri Pangan dan Agro. IPB Press. ISBN. 978-979-493-216-2.

Tahir, M.M., N. Abdullah dan R. Rahmadani. 2014. Formulasi Bumbu Penyedap Berbahan Dasar Ikan Teri (Stolephorusspp.) dan Daging Buah Picung (Pangium edule) dengan Penambahan Rempah-Rempah. Prosiding Seminar dan Lokakarya Nasional FKPTTPI. Riau. 